Yaroslava Dudko,

PhD (Candidate of Pedagogical Sciences), associate professor, doctoral candidate, Department of Pedagogy and Art of Teaching, Bohdan Khmelnytskyi State Pedagogical University of Melitopol, 20, Hetmanska Str., Melitopol, Ukraine

\title{
ORGANISATIONAL AND PEDAGOGICAL CONDITIONS FOR EDUCATIONAL WORK MANAGEMENT AT TEACHER TRAINING UNIVERSITIES OF UKRAINE
}

The paper presents the results of scientific and pedagogical research of the issue of modernisation of educational work management at teacher training universities of Ukraine. The aim of the research work was to specify and substantiate the system of organisational and pedagogical conditions for managing educational work of Ukrainian teacher training universities; develop a factor-and-criterion-based model of assessing the effectiveness of educational work management and carry out its experimental proof. According to scientific literature review and the results obtained at the summative stage of the pedagogical experiment, the following organisational and pedagogical conditions have been distinguished: regulatory (availability of regulatory documents, programme of educational work development, intra-university TV and radio programmes, university website, counselling service, etc.), methodological (organisation of the system of training and retraining of educational work managers, availability of individual plans for educational work managers' development, methodological basis for educational work managers' creative development, etc.), financial (the use of managerial and marketing technologies, employment and sustainable use of extra-budgetary sources, etc.), psycho-pedagogical (creating acmeological environment and incentive system for motivation of educational work managers, atmosphere of respect, trust and success), and organisational (person-centred approach to educational process management, engaging community and parents in education of students, adhering to traditional principles, functions, methods and means in educational work management, etc.). Basing on the qualimetric approach, we have developed a factor-and-criterion-based model for assessing the effectiveness of managing educational work of teacher training universities of Ukraine. The model makes it possible to find existing shortcomings in providing organisational and pedagogical conditions for educational work management at a teacher training university as well as specify the ways of their overcoming. Results of the expert evaluation of the data obtained have made it possible to state that the developed factor-and-criterion-based model for assessing the quality of managing educational work of a pedagogical higher educational institution is effective.

Keywords: education, educational work, pedagogical higher educational institution, a process, self-government, a student, management.

\section{Introduction}

At the current stage of pedagogical education development in Ukraine, the problem of educating coming generation of Ukrainians is relevant and should be solved immediately. The complicated political and socioeconomic situation that has aroused in the Ukrainian society causes the need for the reforming of the national system of youth education in general, and for searching for effecting ways of forming a future teacher's personality in particular. According to the Law of Ukraine "On Higher Education" No. 1556-VII dated 1 July 2014 [1], teacher training universities of Ukraine are facing the task of modernisation of the process of educating young people and creating proper organisational and pedagogical conditions for managing the educational work.

Organisational and pedagogical fundamentals of managing a higher educational institution were considered in research works of domestic and foreign scientists: V. Andrushchenko [2], J. Donelly [3], J. Kotter [4], A. Pokhresnyk [5] et al. Ways of improving the system of educating students in higher education were presented in research works of O. Babichev [6], T. Kiryk [7], I. Yashchuk [8] et al. Peculiarities of organising educational work management at Ukrainian higher educational institutions were studied by A. Kalinichenko [9], A. Rzhevska [10] et al. Scientific literature review demonstrates that providing organisational and pedagogical conditions for educational work management at higher educational institutions of Ukraine remains understudied by Ukrainian researchers and requires further investigation.

The paper aims to specify and substantiate the system of organisational and pedagogical conditions for managing educational work of Ukrainian teacher training universities; develop a factor-and-criterion-based model of assessing the effectiveness of educational work management at a pedagogical higher educational institution and carry out its experimental proof.

Research methods: scientific literature review, content analysis and classification for distinguishing and substantiating organisational and pedagogical conditions for managing educational work of teacher training universities; theoretical modelling, expert evaluation, registration, arranging aimed at the development of the factorand-criterion-based model; pedagogical experiment aimed at proving the effectiveness of the factor-and-criterionbased model; statistical methods for checking significance 
of rank correlation coefficient and validity of the research results.

\section{Discussion}

During 2015-2017 academic years at the educational institutions of Zaporizhzhia, Cherkasy and Kirovohrad regions we have conducted a pedagogical experiment consisting of the preparatory, summative, formative stages, and generalisation of the results obtained. The aim of the experimental work was to single out the system of organisational and pedagogical conditions for managing educational work of teacher training universities of Ukraine and use them as the basis for the development of a factor-and-criterion-based model of assessing the effectiveness of educational work management at a teacher training university. 610 people took part in the experiment.

Results of content analysis of domestic and international research works devoted to the issue under study and results of the summative stage of the experiment (aiming at collecting factual data about current state of educational work management at Ukrainian universities) have made it possible to specify organisational and pedagogical conditions for managing educational work at pedagogical higher educational institutions and classify them into regulatory, informational, methodological, financial, psychopedagogical, and organisational ones.

We have chosen a qualimetric approach to assess the state of organisational and pedagogical conditions for educational work management at teacher training universities. The structure of the qualimetric (factor-andcriterion-based) model involves specification of parameters, factors and criteria of the process of educational work management at the university, which were distinguished with the help of the algorithm of structuring the object under assessment developed by H. Yelnykova [11]. Weight coefficient for each parameter, factor and criteria was calculated by means of expert evaluation method (the Delphi method). In three stages, a group of 15 experts evaluated the significance of each parameter, factor and criteria using ranking method. Statistical data processing was carried out by means of rank correlation method according to the fixed plan: calculating the rank sum for each parameter, factor and criterion; calculating the rank mean value for each parameter, factor and criterion; checking the degree of conformity of the experts' opinions; checking the significance of rank correlation coefficients. The degree of conformity of experts' opinions was checked by means of calculating concordance coefficient (0.804). It demonstrates the high level of conformity of experts' opinions and validity of the data obtained.

Using the above-mentioned results, we have developed a factor-and-criterion-based model of assessing educational work management at teacher training universities (Table 1).

Factor-and-criterion-based model of assessing the effectiveness of

Table 1. educational work management at a pedagogical higher educational institution

\begin{tabular}{|c|c|c|c|c|c|}
\hline & Factors (f) & $\mathbf{V}_{\mathrm{f}}$ & & Criteria (k) & $\mathbf{V}_{\mathbf{k}}$ \\
\hline 1 & 2 & 3 & 4 & 5 & 6 \\
\hline$P 1$ & \multicolumn{5}{|c|}{ Regulatory support of educational work management } \\
\hline$V_{p}$ & & & & & 0.19 \\
\hline \multirow[t]{3}{*}{1} & \multirow{3}{*}{$\begin{array}{l}\text { Fulfilling regulatory require- } \\
\text { ments to the organisation of } \\
\text { educational work management } \\
\text { at the university }\end{array}$} & \multirow[t]{3}{*}{0.42} & 1 & $\begin{array}{l}\text { Availability of regulatory documents required for organising } \\
\text { the process of educational work management }\end{array}$ & 0.32 \\
\hline & & & 2 & $\begin{array}{l}\text { Quality of keeping business documents regulating educational } \\
\text { activities of a higher educational institution }\end{array}$ & 0.26 \\
\hline & & & 3 & $\begin{array}{l}\text { Keeping with the regulatory requirements to implementation } \\
\text { of the process of educational work management }\end{array}$ & 0.42 \\
\hline \multirow[t]{3}{*}{2} & \multirow{3}{*}{$\begin{array}{l}\text { Correspondence of the struc- } \\
\text { ture of educational work man- } \\
\text { agement system to the univer- } \\
\text { sity's strategy of educational } \\
\text { activities development }\end{array}$} & \multirow[t]{3}{*}{0.31} & 1 & $\begin{array}{l}\text { Availability and efficiency of the programme of educational } \\
\text { activities development at the university }\end{array}$ & 0.36 \\
\hline & & & 2 & $\begin{array}{l}\text { Conformity of long-term plans developed by different struc- } \\
\text { tural units concerning an intra-university system of managing } \\
\text { student education }\end{array}$ & 0.30 \\
\hline & & & 3 & $\begin{array}{l}\text { Quality of staffing for managing educational work of a higher } \\
\text { educational institution }\end{array}$ & 0.34 \\
\hline \multirow[t]{2}{*}{3} & \multirow[t]{2}{*}{$\begin{array}{l}\text { Managers'* knowledge of the } \\
\text { regulatory support of educa- } \\
\text { tional work performed at the } \\
\text { university }\end{array}$} & \multirow[t]{2}{*}{0.27} & 1 & $\begin{array}{l}\text { Appropriate conditions providing managers' knowledge of } \\
\text { the regulatory support of educational activities }\end{array}$ & 0.38 \\
\hline & & & 3 & Self-control over regulatory requirements fulfilment & 0.26 \\
\hline
\end{tabular}




\begin{tabular}{|c|c|c|c|c|c|}
\hline & Factors (f) & $\mathbf{V}_{\mathbf{f}}$ & & Criteria (k) & $\mathbf{V}_{\mathbf{k}}$ \\
\hline 1 & 2 & 3 & 4 & 5 & 6 \\
\hline$P 2$ & \multicolumn{5}{|c|}{ Informational support of educational work management } \\
\hline$V_{p}$ & & & & & 0.1 \\
\hline \multirow[t]{3}{*}{$\mathbf{1}$} & \multirow[t]{3}{*}{$\begin{array}{l}\text { Informational provision of } \\
\text { educational work management } \\
\text { system }\end{array}$} & \multirow[t]{3}{*}{0.37} & 1 & $\begin{array}{l}\text { Existence of the system of informational support of the pro- } \\
\text { cess of educational work management at a higher educational } \\
\text { institution }\end{array}$ & 0.41 \\
\hline & & & 2 & $\begin{array}{l}\text { Quality of information accumulation, processing, systematisa- } \\
\text { tion and storage }\end{array}$ & 0.31 \\
\hline & & & 3 & $\begin{array}{l}\text { Availability of intra-university TV and radio programmes, } \\
\text { website of a university }\end{array}$ & 0.28 \\
\hline \multirow[t]{4}{*}{2} & \multirow[t]{4}{*}{$\begin{array}{l}\text { Creating environment for } \\
\text { educational work managers' } \\
\text { informational awareness }\end{array}$} & \multirow[t]{4}{*}{0.33} & 1 & $\begin{array}{l}\text { Quality of work performed by structural units or correspond- } \\
\text { ing information services concerning new research and devel- } \\
\text { opment in the field of educating students }\end{array}$ & 0.31 \\
\hline & & & 2 & $\begin{array}{l}\text { Level of managers' awareness of innovative development of } \\
\text { the educational environment }\end{array}$ & 0.28 \\
\hline & & & 3 & $\begin{array}{l}\text { Availability and completeness of pedagogical innovation } \\
\text { bank of a university }\end{array}$ & 0.19 \\
\hline & & & 4 & service & 0.22 \\
\hline \multirow[t]{3}{*}{3} & \multirow{3}{*}{$\begin{array}{l}\text { Public information about re- } \\
\text { sults of the process of student } \\
\text { education management }\end{array}$} & \multirow[t]{3}{*}{0.3} & 1 & Publishing a & 0.30 \\
\hline & & & 2 & $\begin{array}{l}\text { Regular provision of information concerning students' } \\
\text { achievements via public communications }\end{array}$ & 0.37 \\
\hline & & & 3 & $\begin{array}{l}\text { Opportunity for intra-university publishing of managers' } \\
\text { preliminary studies }\end{array}$ & 0.33 \\
\hline P3 & \multicolumn{5}{|c|}{ Methodological support of educational work management } \\
\hline$V_{p}$ & & & & & 0.19 \\
\hline \multirow[t]{5}{*}{1} & \multirow{5}{*}{$\begin{array}{l}\text { Quality of university's meth- } \\
\text { odological background for } \\
\text { creative development of edu- } \\
\text { cational work managers }\end{array}$} & \multirow[t]{5}{*}{0.35} & 1 & $\begin{array}{l}\text { Availability and level of university's multimedia library de- } \\
\text { velopment }\end{array}$ & 0.22 \\
\hline & & & 2 & $\begin{array}{l}\text { Existence and performance of Educational Work Council at } \\
\text { the higher educational institution }\end{array}$ & 0.26 \\
\hline & & & 3 & $\begin{array}{l}\text { Level of training and educational process integration in higher } \\
\text { education }\end{array}$ & 0.21 \\
\hline & & & 4 & $\begin{array}{l}\text { Quality of collaboration with research, cultural, recreational, } \\
\text { and sports institutions, etc }\end{array}$ & \\
\hline & & & 5 & & 0.13 \\
\hline \multirow[t]{2}{*}{2} & \multirow{2}{*}{$\begin{array}{l}\text { Training and retraining of } \\
\text { educational work managers for } \\
\text { the organisation of student } \\
\text { education at a higher educa- } \\
\text { tional institution }\end{array}$} & \multirow[t]{2}{*}{0.28} & 1 & $\begin{array}{l}\text { Quality of the system of managers' readiness for educational } \\
\text { work organisation }\end{array}$ & 0.33 \\
\hline & & & 2 & $\begin{array}{l}\text { Effectiveness of the system of training and retraining of edu- } \\
\text { cational work managers }\end{array}$ & 0.67 \\
\hline \multirow[t]{3}{*}{3} & \multirow{3}{*}{$\begin{array}{l}\text { Providing creative atmosphere } \\
\text { for educational work managers } \\
\text { of a higher educational institu- } \\
\text { tion }\end{array}$} & \multirow[t]{3}{*}{0.21} & 1 & $\mathrm{ch}$ & 0.39 \\
\hline & & & 2 & $\begin{array}{l}\text { Participation of educational work managers in res } \\
\text { nars, conferences, contests, cultural events, excurs }\end{array}$ & 0.28 \\
\hline & & & 3 & Level of creativity of educational work managers & 0.33 \\
\hline \multirow[t]{3}{*}{4} & \multirow{3}{*}{$\begin{array}{l}\text { Self-improvement of educa- } \\
\text { tional work managers }\end{array}$} & \multirow[t]{3}{*}{0.16} & 1 & Avallabillity & 0.35 \\
\hline & & & 2 & $\begin{array}{l}\text { Level of educational work managers' aiming for self-study, } \\
\text { self-education, self-improvement }\end{array}$ & 0.37 \\
\hline & & & 3 & Focus of managers' self-study on innovations & 0.28 \\
\hline$P 4$ & \multicolumn{5}{|c|}{ Financial support of educational work management } \\
\hline$V_{p}$ & & & & & 0.1 \\
\hline \multirow[t]{2}{*}{1} & \multirow{2}{*}{\begin{tabular}{|l|} 
Use of managerial and market- \\
ing technologies
\end{tabular}} & \multirow[t]{2}{*}{0.38} & 1 & & 0.31 \\
\hline & & & 2 & Implementation of marketing technologies & 0.31 \\
\hline
\end{tabular}




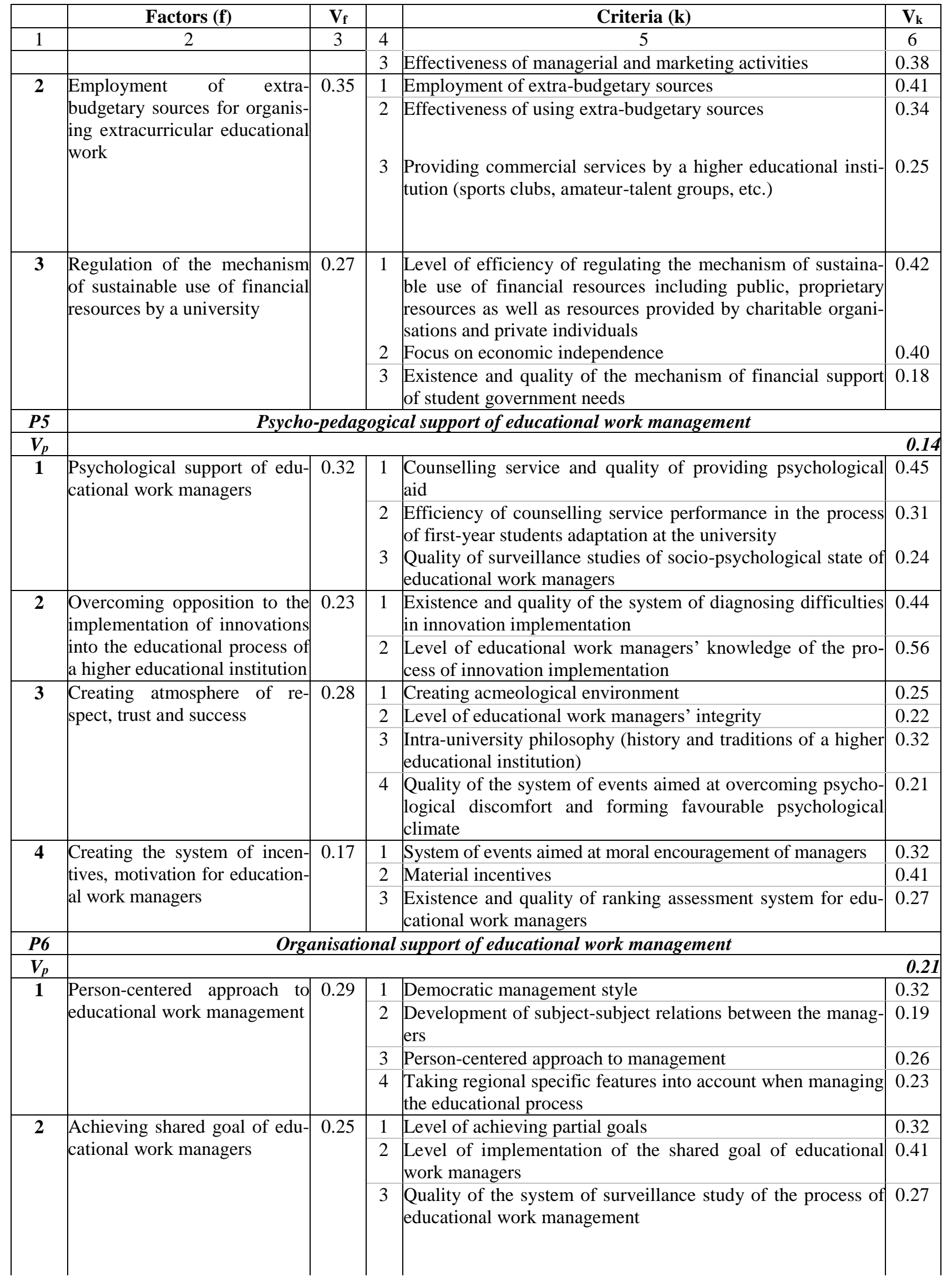




\begin{tabular}{|c|c|c|c|c|c|}
\hline & Factors (f) & $\mathbf{V}_{\mathbf{f}}$ & & Criteria (k) & $\mathbf{V}_{\mathbf{k}}$ \\
\hline 1 & 2 & 3 & 4 & 5 & 6 \\
\hline \multirow[t]{2}{*}{3} & \multirow{2}{*}{$\begin{array}{l}\text { Fulfilment of organisational } \\
\text { and pedagogical requirements } \\
\text { to managing educational work } \\
\text { of a higher educational institu- } \\
\text { tion }\end{array}$} & \multirow[t]{2}{*}{0.21} & 1 & $\begin{array}{l}\text { Adhering to traditional principles, functions, methods and } \\
\text { means in educational work management } \\
\text { Adhering to innovative principles, functions, methods and } \\
\text { means of educational work management }\end{array}$ & 0.42 \\
\hline & & & 3 & $\begin{array}{l}\text { Existence and performance of additional innovative units of } \\
\text { intra-university system of education }\end{array}$ & 0.37 \\
\hline \multirow[t]{2}{*}{4} & \multirow[t]{2}{*}{$\begin{array}{l}\text { Formation of student govern- } \\
\text { ment bodies }\end{array}$} & \multirow[t]{2}{*}{0.15} & $\begin{array}{l}1 \\
2\end{array}$ & $\begin{array}{l}\text { Existence and performance of student government } \\
\text { System of events aimed at engaging students into participa- } \\
\text { tion in student government }\end{array}$ & $\begin{array}{l}0.44 \\
0.35\end{array}$ \\
\hline & & & 3 & $\begin{array}{l}\text { Quality of the system of training personnel for student gov- } \\
\text { ernment of a university }\end{array}$ & 0.31 \\
\hline \multirow[t]{3}{*}{5} & \multirow[t]{3}{*}{$\begin{array}{l}\text { Engaging community and } \\
\text { parents in student education }\end{array}$} & \multirow[t]{3}{*}{0.10} & 1 & $\begin{array}{l}\text { Level of parents' participation in the educational process of a } \\
\text { higher educational institution }\end{array}$ & 0.27 \\
\hline & & & 2 & $\begin{array}{l}\text { Existence and performance of youth public organisations at a } \\
\text { higher educational institutions }\end{array}$ & 0.34 \\
\hline & & & 3 & Public relations & 0.39 \\
\hline
\end{tabular}

* We mean academic staff responsible for managing educational work of a higher educational institution

The developed factor-and-criterion-based model makes it possible to comprehensively assess the level of providing organisational and pedagogical conditions for managing educational work of a higher educational institution according to the classical grading system ( 0 to 5 points): "0-1" - unacceptable level; "1-2" - critical (low) level; "2-3" - sufficient (average) level; "3-4" - high (above the average) level; " $4-5$ " - excellent level. Therefore, the point for each factor was calculated as a total of products of points for each criterion and corresponding weight coefficients, the point for each parameter - as a total of products of points for each factor and the corresponding weight coefficient, the point for the object - as a total of points for parameters. Also, we have developed a software application and guidelines for experts regarding the use of the model.

The developed model was tested at 9 pedagogical higher educational institutions of Zaporizhzhia, Cherkasy and Kirovohrad regions by independent group of experts and administration of these educational institutions for self-assessment. Long-term and repeated use of the model by experts has made it possible to check its validity and, using the rules of experimental data binning, to distinguish four levels of effectiveness of the process of educational work management at a higher educational institution (initial, acceptable, sufficient, and optimum). Results of the expert evaluation of the data obtained have made it

\section{REFERENCES}

1. Zakon Ukrainy "Pro vyshchu osvitu” 1.07.2014 № 1556-VII [The Law of Ukraine "On higher education" No. 1556-VII dated 1 July 2014]. (2014). $z a$ kon4.rada.gov.ua. Retrieved from: http://zakon4.rada.gov.ua/laws/show/1556-18/page [in Ukrainian].

2. Andrushchenko, V. (2011). Universytetska osvita Ukrainy: yevropeiskyi vybir [University education in possible to state that the developed factor-and-criterionbased model for assessing the quality of managing educational work of a pedagogical higher educational institution is effective.

\section{Conclusions}

Analysis of the results of the experimental work has made it possible to conclude that the developed factorand-criterion-based model is a comprehensive tool for assessment of the process of educational work management at universities, which makes it possible to find shortcomings in providing organisational and pedagogical conditions for educational work management at a teacher training university as well as specify the ways of their overcoming. The developed model can be used in research and development for further studies of the main trends of development of the process of student education management; in procedural and practical sphere - as theoretical material for developing a specialised course for career development of university leaders as well as for master-degree students majoring in management, pedagogy of higher education; in education management - for objective evaluation and self-evaluation of the managerial process at a higher educational institution. It is planned to focus further research on the development of technologies of managing educational work of a teacher training university

Ukraine: European choice]. Osvita - Education, 40-41, 45 [in Ukrainian].

3. Donelly, J., Gibson, J., \& Ivancevich, J. (2006). Fundamentals of management. Chicago, NY: Irwin [in English].

4. Kotter, J. (2007). Professional development for education management. London, NY: Open University Press [in English]. 
5. Pokhresnyk, A. (2013). Osvitno-filosofskyi analiz osoblyvostei suchasnoho stanu i tendentsii zminy sfery navchannia i vykhovannia [Educational and philosophical analysis of the characteristics of the current state and trends in the areas of training and education]. Vyshcha osvita Ukrainy - Higher education of Ukraine, 1, 69-74 [in Ukrainian].

6. Babichev, O. I., Khrykov, Ye. M., \& Rzhevska, A. V. (2000). Systema vykhovnoi roboty u vyshchomu navchalnomu zakladi [The system of educational work in higher educational institution]. Vykhovna robota $v$ suchasnomu vyshchomu navchalnomu zakladi - Educational work in a modern higher educational institution. (pp. 10-18). Luhansk [in Ukrainian].

7. Kiryk, T. (2014). Aktualnist zavdannia formuvannia osobystosti studenta $\mathrm{v}$ umovakh yevropeiskykh nadii Ukrainy [The relevance of the task of forming a student personality under the conditions of Ukraine's European hopes]. Vyshcha osvita Ukrainy - Higher education of Ukraine, 5, 101-108 [in Ukrainian].

\section{ЛІТЕРАТУРА}

1. Закон України «Про вищу освіту» від 1.07.2014 г. № 1556-VII [Електронний ресурс]. - Режим http://zakon4.rada.gov.ua/laws/show/1556-18/page.

2. Андрущенко В. Університетська освіта України : європейський вибір / В. Андрущенко // Освіта. 2001. - № 40-41 (25 липня - 1 серпня). - С. 4-5.

3. Donelly J. Fundamentals of management / J. Donelly, J. Gibson, J. Ivancevich. - Chicago : Irwin, 2006. - 719 p.

4. Kotter J. Proffesional development for education management / J. Kotter. - London : Open University Press, 1997. -201 p.

5. Похресник А. Освітньо-філософський аналіз особливостей сучасного стану і тенденцій зміни сфери навчання і виховання / А. Похресник // Вища освіта України. - 2013. - № 1. - С. 69-74.

6. Бабічев О. І. Система виховної роботи у вищому навчальному закладі / О. І. Бабічев, А. В. Ржевська // Виховна робота в сучасному вищому навчальному закладі : метод. посіб. / О. І. Бабічев, Є. М. Хриков, Г. В. Ржевська та ін. - Луганськ, 2000. - С. 10-18.

8. Yashchuk, I. P. (2011). Teoriia ta praktyka vykhovannia studentskoi molodi $\mathrm{v}$ vyshchykh pedahohichnykh zakladakh Ukrainy (1920-1991 rr.) [Theory and practice of student education at higher educational institutions of Ukraine (1920-1991 years)]. Doctor's thesis. Khmelnytskyi [in Ukrainian].

9. Kalinichenko, A. I. (2002). Pedahohichni umovy orhanizatsii samovykhovannia studentskoi molodi [Pedagogical conditions of organization of student selfeducation]. Extended abstract of candidate's thesis. Ternopil [in Ukrainian].

10. Rzhevska, A. V. (2001). Vykhovannia hromadianskosti u studentiv vyshchykh navchalnykh zakladiv [Instilling sense of nationhood in students of higher educational institution]. Teoretyko-metodychni problemy vykhovannia ditei ta uchnivskoi molodi - Theoretical and methodological problems of education of children and youth. (Vols. 1). (pp. 94-100). Kyiv [in Ukrainian].

11. Yelnykova, H. V. (2005). Upravlinska kompetentnist [Managerial competence]. Kyiv: Red. zahalnoped. haz. [in Ukrainian].

7. Кірик Т. Актуальність завдання формування особистості студента в умовах європейських надій України / Т. Кірик // Вища освіта України. - 2014. № 5. - С. 101-108.

8. Ящук I. П. Теорія та практика виховання студентської молоді у вищих педагогічних закладів України (1920-1991 рр.) : дис. ... д-ра. пед. наук : 13.00.01 «Загальна педагогіка та історія педагогіки» / Інна Петрівна Ящук. - Хмельницький, 2011. - 513 с.

9. Калініченко А. І. Педагогічні умови організації самовиховання студентської молоді : автореф. дис. ... канд. пед. наук : 13.00 .04 «Теорія і методика професійної освіти» / А. І. Калініченко. - Тернопіль, 2002. $16 \mathrm{c}$.

10. Ржевська А. В. Виховання громадянськості у студентів вищих навчальних закладів / А. В. Ржевська // Теоретико-методичні проблеми виховання дітей та учнівської молоді : збірник наук. праць. - Київ, 2001. - Кн. I - C. 94-100.

11. Єльникова Г. В. Управлінська компетентність / Г. В. Сльникова. - К. : Ред. загальнопед. газ., 2005. $128 \mathrm{c}$.

Ярослава Вікторівна Дудко, кандидат педагогічних наук, доиент, докторант кафедри педагогіки і педагогічної майстерності, Мелітопольський державний педагогічний університет імені Богдана Хмельницького, вул. Гетьманська, 20, м. Мелітополь, Украӥна

\section{ОРГАНІЗАЦІЙНО-ПЕДАГОГІЧНІ УМОВИ УПРАВЛІННЯ ВИХОВНОЮ РОБОТОЮ У ВИЩИХ ПЕДАГОГІЧНИХ НАВЧАЛЬНИХ ЗАКЛАДАХ УКРАЇНИ}

У статті подано результати науково-педагогічного дослідження проблеми модернізації процесу управління виховною роботою у вищих педагогічних навчальних закладах України, що залишається на сьогоднішній день недостатньо розробленою сучасними науковцями і потребує подальшого дослідження. Метою дослідно- 
експериментальної роботи було визначити систему організаційно-педагогічних умов управління виховною роботою у вищих педагогічних навчальних закладах та на їх основі розробити факторно-критеріальну модель оцінювання ефективності процесу управління виховною роботою у вищому педагогічному навчальному закладі. Результати контент-аналізу наукових праць провідних вітчизняних та зарубіжних науковців із проблеми дослідження та результати констатувального етапу експерименту надали можливість визначити систему організаційно-педагогічних умов управління виховною роботою у вищих педагогічних навчальних закладах: нормативно-правові (наявність нормативно-правових документів необхідних для організації процесу управління виховною роботою, дієвість програми розвитку виховної діяльності, узгодженість перспективних планів структурних підрозділів внутрішньовузівської системи управління вихованням студентів, обізнаності суб'єктів управління з нормативним забезпеченням виховної діяльності у вищій школі), інформаційні (наявність системи інформаційного забезпечення процесу управління виховною роботою, внутрішньовузівських теле-, радіопрограм, газети, Інтернет-сайту, банків педагогічних інновацій, структурних підрозділів або відповідних інформаційних служб про нові наукові розробки щодо проблеми виховання студентів, консалтингової служби, створення середовища інформаційної обізнаності суб'єктів управління виховною роботою у вищій школі), науково-методичні (організація системи підготовки та перепідготовки суб'єктів до управління виховною роботою, наявність індивідуальних планів розвитку суб’єктів управління виховною роботою, науково-методичної бази для творчого розвитку суб'єктів управління виховною роботою, системи діагностики готовності суб'єктів управління до організації виховної роботи у вищій школі), матеріально-фінансові (використання технологій менеджменту і маркетингу, залучення додаткових позабюджетних коштів для організації позааудиторної виховної роботи; створення механізму раціонального використання фінансових ресурсів у вищому педагогічному навчальному закладі), психолого-педагогічні (створення акмеологічного середовища та системи стимулів, мотивації суб'єктів управління до виховної діяльності у вищій школі, наявність системи психологічної підтримки суб'єктів управління, подолання супротиву до впровадження інновацій у виховний процес, створення атмосфери поваги, довіри та успіху), організаційні (персоналізований підхід в управлінні виховним процесом, дієвість системи заходів щодо досягнення загальної мети суб'єктів управління виховною роботою, дотримання інноваційних принципів, функцій, методів і засобів управління виховною роботою у вищій школі, формування органів студентського самоуправління, залучення громадськості, батьків до виховання студентської молоді). На основі кваліметричного підходу було розроблено та експериментально перевірено факторно-критеріальну модель оцінювання ефективності процесу управління виховною роботою у вищому педагогічному навчальному закладі. Запропонована модель не тільки дозволяе з'ясувати недоліки у забезпеченні організаційнопедагогічних умов управління виховною роботою у вищому педагогічному навчальному закладі, а й окреслити шляхи їх подолання, таким чином ії ефективність було підтверджено.

Ключові слова: виховання, виховна робота, вищий педагогічний навчальний заклад, процес, самоуправління, студент, управління.

Submitted on May, 11, 2017

Reviewed by Doctor of Pedagogy, prof. I. Anosov 